\title{
STABILITAS MIKROEMULSI VCO DALAM AIR PADA VARIASI HLB DARI TIGA SURFAKTAN SELAMA PENYIMPANAN
}

\author{
Natalie Indirasvari K. S.1), I Dewa Gede Mayun Permana ${ }^{2)}$, ( Ketut Suter ${ }^{2)}$ \\ ${ }^{1)}$ Mahasiswa Program Studi Ilmu dan Teknologi Pangan, Fakultas Teknologi Pertanian, Unud \\ ${ }^{2}$ Dosen Program Studi Ilmu dan Teknologi Pangan, Fakultas Teknologi Pertanian, Unud \\ Kampus Bukit Jimbaran, Badung-Bali
}

\begin{abstract}
Microemulsion is a dispersion system developed from emulsions, which is an oil dispersion system in water, stabilized by a surfactant. Oil-in-water (o/w) microemulsion is an emulsion system suitable for encapsulation and carrier of lipophilic components in the beverage industry. The food grade microemulsion formulation is limited by the type of surfactant that can be used. This research aims to obtain an o/w microemulsion formulation which is stable during storage using three surfactants. In this study, 3 types of food grade surfactants were used, Tween 80, Tween 20, and Span 80, and the oil used is Virgin Coconut Oil (VCO). This research is done in two stages. The first stage of research was the determination of the best microemulsion of 5 variations of HLB: 11,12,13,14, and 15. The second stage is the storage stability test of the microemulsion chosen in the first stage for 7 weeks with observation every week. The data obtained were analyzed by ANOVA. The results of the study shows that $H L B 11,12,13,14$, and 15 obtained by using 3 surfactants can produce microemulsions. The optimum HLB to obtain the best microemulsion stability is HLB 13. The microemulsion with HLB 13 obtained using 3 surfactants is stable during time of 7 weeks storage.
\end{abstract}

Keywords : microemulsion, HLB, storage stability

\section{PENDAHULUAN}

Mikroemulsi merupakan suatu sistem dispersi yang dikembangkan dari emulsi, yaitu suatu sistem dispersi minyak dengan air yang distabilkan oleh lapisan antarmuka dari molekul surfaktan. Karakteristik mikroemulsi memiliki banyak kelebihan dibandingkan dengan emulsi biasa. Karakteristik tersebut antara lain bersifat stabil secara termodinamika, jernih, transparan, viskositasnya rendah, serta mempunyai tingkat solubilisasi yang tinggi sehingga dapat meningkatkan bioavailabilitas bahan yang dibawa tersebut di dalam tubuh (Bakan $d k k$, 1995).

Idealnya mikroemulsi terbentuk dari campuran antara cairan polar dan non-polar.
Di bidang teknologi pangan, mikroemulsi umumnya merupakan campuran air dan minyak. Tergantung cairan mana yang berperan sebagai pendispersi dan terdispersi. Mikroemulsi dibedakan menjadi 2 tipe, yaitu tipe mikroemulsi minyak dalam air $(\mathrm{o} / \mathrm{w})$ dan tipe air dalam minyak (w/o). Paling tidak ada dua cairan yang tidak saling melarutkan terlibat pada pembentukan mikroemulsi. Salah satu cairan merupakan fase internal, sedangkan cairan yang lain merupakan fase eksternal (Hadiwitoyo, 2011).

Emulsi o/w terdiri atas droplet minyak yang dikelilingi oleh lapisan antarmuka tipis yang terdiri dari molekul-molekul surfaktan, terdispersi dalam fase kontinyu yang aqueous (McClements $d k k$., 2007). Menurut Rao dan McClements (2012), nanoemulsi dan

*Korespondensi Penulis:

Email: indirasvari@gmail.com ${ }^{1}$ 
mikroemulsi o/w merupakan dua jenis sistem emulsi yang cocok untuk enkapsulasi dan pembawa komponen lipofilik pada industri minuman. Sistem pembawa berbasis emulsi minyak dalam air merupakan cara yang sangat cocok untuk enkapsulasi, perlindungan dan membawa komponen bioaktif yang tidak larut air dalam rangka aplikasi pangan fungsional sehingga meningkatkan solubilitas dan bioaktivitasnya (Chakrabarty, 2010).

Virgin Coconut Oil(VCO) merupakan minyak yang berasal dari buah kelapa tua segar yang dapat dikonsumsi karena baik untuk kesehatan. VCO mengandung asamasam lemak jenuh yang tinggi yang menjadikannya tidak mudah tengik. Asam lemak jenuh dalam VCO sebagian besar adalah asam laurat. Asam lemak yang terdapat pada VCO mirip dengan lemak yang terdapat pada Air Susu Ibu (ASI) dan mempunyai efek nutrisi yang sama. VCO juga dikenal karena komponen anti mikrobanya (Haerani, 2010).

Sistem mikromulsi yang stabil membutuhkan surfaktan dengan nilai keseimbangan hidrofilik-lipofilik (Hydrophilic Lipophilic Balance) atau HLB yang tepat. HLB suatu surfaktan adalah skala empiris berdasarkan pada persentase relatif kelompok fungsional hidrofilik dan lipofilik dalam molekul surfaktan. Nilai HLB ini berkisar antara 1 sampai 20, dimana angka yang lebih rendah pada umumnya menunjukkan kelarutan dalam minyak (lipofilik) dan angka yang lebih tinggi menunjukkan kelarutan dalam air (hidrofilik) (Griffin , 1949).

HLB yang tepat dari surfaktan, dalam suatu emulsi, biasanya digunakan lebih dari satu surfaktan. Kombinasi dari beberapa surfaktan akan menambah kesempurnaan sifat fisik maupun kimia dari emulsi. Selain memiliki gugus polar dan non-polar dalam satu molekulnya, suatu surfaktan memiliki kemampuan untuk menurunkan tegangan antar muka dan tegangan permukaan (Davies, 1957). Dengan tegangan antar muka yang rendah yang didapatkan dari kombinasi surfaktan tersebut, mikroemulsi yang dihasilkan akan lebih stabil.

Surfaktan nonionik seperti ester sorbitan (Span), ester asam lemak polioksietilen sorbitan (Tween), dan eter polioksietilena telah banyak digunakan dalam persiapan mikroemulsi karena toksisitas dan potensi iritasi yang relatif rendah (Flanagan $d k k$, 2006). Tween memiliki toksisitas minimal dan bernilai komersial rendah, sehingga banyak digunakan dalam industri pangan, kosmetik, dan aplikasi farmasi (Yaghmur $d k k, 2002$ ).

Penelitian ini difokuskan pada formulasi mikroemulsi food grade sebagai sistem pembawa dalam produk pangan. Dalam penelitian ini, tiga jenis surfaktan dipilih dan dianalisis kemampuannya dalam pembentukan mikroemulsi, yaitu: Span 80, Tween 20, dan Tween 80. Penelitian ini bertujuan untuk menentukan formulasi mikroemulsi VCO dalam air terbaik dari 5 HLB yang didapat dengan menggunakan variasi rasio surfaktan, kemudian menentukan stabilitasnya selama penyimpanan.

\section{METODE PENELITIAN}

\section{Alat dan Bahan}

Peralatan yang digunakan dalam penelitian ini adalah: gelas beker, tabung reaksi, magnetic stirrer, hot plate Fisher Scientific, vortex Labnet, buret, pipet mikro, spektrofotometer UV-Vis (Evolution 201), oven WiseTherm, centrifuge Clements GS 150, $\mathrm{pH}$ meter.

Bahan yang digunakan dalam penelitian terdiri dari bahan baku mikroemulsi yaitu, Virgin Coconut Oil (VCO), Tween 80 merek Merck, Span 80 merek Merck, Tween 20 merek Merck, asam sitrat, sodium sitrat dan aquades.

\section{Rancangan Penelitian}

Penelitian ini dilaksanakan dalam dua tahap. Tahap pertama merupakan penelitian pembuatan mikroemulsi untuk menentukan 
HLB terbaik. Rancangan yang digunakan adalah Rancangan Acak Kelompok (RAK) dengan 2 kali ulangan. Perlakuan yang diberikan adalah perbedaan HLB yaitu HLB
11, HLB 12, HLB 13, HLB 14 dan HLB 15, menggunakan tiga surfaktan dengan komposisi seperti pada Tabel 1.

Tabel 1. Perbandingan 3 surfaktan untuk mendapatkan HLB

\begin{tabular}{cccc}
\hline & \multicolumn{3}{c}{ Perbandingan surfaktan } \\
\cline { 2 - 4 } Nilai HLB & Tween 80 & Span 80 & Tween 20 \\
\hline HLB 11 & 69,42 & 2 & 3 \\
HLB 12 & 76,08 & 2 & 3 \\
HLB 13 & 82,7 & 2 & 3 \\
HLB 14 & 89,42 & 2 & 3 \\
HLB 15 & 93,5 & 1 & 2 \\
\hline
\end{tabular}

Penelitian tahap kedua dilakukan setelah menentukan mikroemulsi dengan HLB terbaik untuk kemudian diuji stabilitasnya selama penyimpanan. Rancangan yang digunakan adalah Rancangan Acak Lengkap (RAL) dengan dua kali ulangan. Perlakuan yang diberikan adalah waktu penyimpanan. Penyimpanan dilakukan selama 7 minggu, dengan pengamatan setiap minggunya. Perlakuan diulang sebanyak 2 kali sehingga diperoleh 16 unit percobaan.

Data yang diperoleh dianalisis dengan analisis ragam, apabila berpengaruh nyata $(\mathrm{P}<0,05)$ terhadap variabel yang diamati maka dilanjutkan dengan uji perbandingan berganda Duncan (Steel dan Torrie, 1993).

\section{Pelaksanaan Penelitian \\ Tahap Pertama}

Proses pembuatan mikroemulsi dimulai dengan mencampurkan 3 jenis surfaktan sebanyak 3,6 ml sesuai dengan perbandingan, untuk mendapatkan HLB 11, 12, 13, 14 dan 15. Selanjutnya $3,6 \mathrm{ml}$ surfaktan dan $0,4 \mathrm{ml}$ VCO dicampur sehingga perbandingannya 90:10. Bahan-bahan ini dicampurkan di dalam gelas beker dan dipanaskan diatas hot plate dengan suhu $70^{\circ} \mathrm{C}$, sambil diaduk menggunakan magnetic stirrer. Campuran ini kemudian ditambahkan aquades sebanyak 16 $\mathrm{ml}$ secara bertahap menggunakan buret, sehingga campuran tersebut terdiri dari $80 \%$ aquades. Formula yang menghasilkan mikroemulsi ditandai dengan kenampakannya yang jernih (transparan).

Variabel yang diamati pada penelitian ini yaitu turbiditas, stabilitas terhadap pemanasan, stabilitas terhadap $\mathrm{pH}$, stabilitas terhadap gaya sentrifugasi, dan stabilitas selama penyimpanan. Formula yang menghasilkan mikroemulsi diuji stabilitas fisiknya menurut metoda yang dilaporkan oleh Cho $d k k$. (2008).

Uji turbiditas dilakukan dengan memasukkan sampel ke dalam kuvet dengan lebar $1 \mathrm{~cm}$ kemudian absorbansi sampel diukur menggunakan spektrofotometer UV-VIS pada panjang gelombang $502 \mathrm{~nm}$ (Cho dkk., 2008). Turbiditas dihitung dengan persamaan berikut:

$$
\text { Turbiditas }(\%)=\frac{2,303 \times \text { absorbansi }}{\text { lebar kuvet }(\mathrm{cm})}
$$

Formula yang menghasilkan mikroemulsi yang baik, ditandai dengan kenampakannya jernih (transparan) dan turbiditasnya kurang dari 1\% (Fletcher dan Suhling, 1998).

Uji stabilitas mikroemulsi dilakukan pada mikroemulsi yang disimpan pada suhu kamar, dan uji stabilitas dipercepat dilakukan dengan pemanasan mikroemulsi pada suhu $105^{\circ} \mathrm{C}$ selama 5 jam dengan oven kemudian diuji turbiditasnya.

Sentrifugasi dilakukan dengan mengambil sampel mikroemulsi $(10 \mathrm{ml})$ dan disentrifugasi pada $4500 \mathrm{rpm}$ selama 30 menit, kemudian diuji turbiditasnya. 
Pengujian stabilitas terhadap $\mathrm{pH}$ dilakukan dengan mengencerkan mikroemulsi dengan media buffer sitrat $\mathrm{pH} \mathrm{3,5}$ dan 4,5. Masingmasing sampel dibuat dua perbandingan pengenceran dengan proporsi 1:1 dan 1:9. Menghasilkan empat sampel yang diuji yaitu pengenceran 1:1 dengan $\mathrm{pH} 3,5$; pengenceran 1:1 dengan $\mathrm{pH} 4,5$; pengenceran 1:9 dengan $\mathrm{pH} 3,5$; serta pengenceran 1:9 dengan $\mathrm{pH} 4,5$. Selanjutnya mikroemulsi dihitung turbiditasnya, dan diamati terbentuk atau tidaknya gel (Cho dkk., 2008).

\section{Tahap Kedua}

Sampel mikroemulsi disimpan selama 7 minggu dan diamati setiap minggu.
Pengamatan dilakukan dengan melihat terjadinya pemisahan atau tidak, serta penghitungan turbiditas. Mikroemulsi dikatakan stabil apabila diakhir masa penyimpanan, kenampakan mikroemulsi tetap transparan, tidak terbentuk endapan dan mempunyai indeks turbiditas kurang dari $1 \%$ (Cho dkk., 2008).

\section{HASIL DAN PEMBAHASAN}

\section{Penentuan HLB untuk Mendapatkan Mikroemulsi VCO dalam Air yang Terbaik}

Nilai turbiditas dari hasil kedua pengulangan ini dapat dilihat pada Tabel 2 .

Tabel 2. Nilai turbiditas rata-rata dari sampel mikroemulsi (\%).

\begin{tabular}{lccc}
\hline \multirow{2}{*}{ HLB } & \multicolumn{3}{c}{ Turbiditas $(\%)$} \\
\cline { 2 - 4 } & Awal & Setelah pemanasan & Setelah sentrifugasi \\
\hline 11 & $0,05520 \pm 0,003$ & $0,07255 \pm 0,001$ & $0,06325 \pm 0,001$ \\
12 & $0,05290 \pm 0,006$ & $0,03105 \pm 0,004$ & $0,05520 \pm 0,000$ \\
13 & $0,04945 \pm 0,004$ & $0,01495 \pm 0,001$ & $0,05635 \pm 0,001$ \\
14 & $0,06095 \pm 0,004$ & $0,05865 \pm 0,001$ & $0,05405 \pm 0,008$ \\
15 & $0,05175 \pm 0,001$ & $0,05175 \pm 0,004$ & $0,04025 \pm 0,001$ \\
\hline
\end{tabular}

\section{Turbiditas Awal}

Hasil analisis keragaman menunjukkan bahwa turbiditas awal dari ke-lima HLB tidak berbeda nyata $(\mathrm{P}>0,05)$, semua HLB menghasilkan mikroemulsi yang transparan, tidak terjadi pemisahan, dan nilai turbiditasnya dibawah $1 \%$. Namun dari semua hasil ini terlihat bahwa dari nilai ratarata mikroemulsi dengan HLB 13 menghasilkan turbiditas paling rendah, yang merupakan hasil yang terbaik dan dapat dilanjutkan uji tahap kedua yaitu stabilitas terhadap penyimpanan.

Pada mikroemulsi o/w, HLB rendah cenderung berada dibagian dalam sedangkan HLB lebih tinggi cenderung berada bagian luar dengan ekor hidrokarbon saling berdekatan yang dapat meningkatkan partisi lapisan antarmuka (Cho et al., 2008). Surfaktan mempunyai angka HLB sesuai dengan struktur kimianya. Molekul dengan angka HLB tinggi mempunyai rasio kelompok hidrofilik lebih besar dibandingkan kelompok lipofilik, dan sebaliknya. Span 80 $($ HLB $=4,3)$ bersifat hidrofobik kemungkinan berada dibagian dalam dan Tween $80($ HLB $=15)$ kemungkinan berada bagian luar, sedangkan Tween 20 (HLB = 16,7) kemungkinan berada bagian paling luar diantara Tween 80. Tween 20 keberadaan diantara Tween 80 pada bagian luar membentuk partisi lebih rapat pada bagian antar muka mikroemulsi. Cho et al.(2008) melaporkan bahwa campuran surfaktan dengan nilai HLB yang berbeda dapat meningkatkan stabilitas, karena membentuk partikel kecil dan dapat meningkatkan kelarutan. 


\section{Turbiditas Setelah Uji Pemanasan}

Hasil analisis keragaman menunjukkan bahwa turbiditas setelah uji pemanasan dari ke-lima HLB tidak berbeda nyata $(\mathrm{P}>0,05)$, semua HLB menghasilkan mikroemulsi yang transparan, tidak terjadi pemisahan, dan nilai turbiditasnya dibawah $1 \%$. Namun dari semua hasil ini terlihat bahwa mikroemulsi dengan HLB 13 menghasilkan turbiditas paling rendah, yang merupakan hasil yang terbaik dan dapat dilanjutkan uji tahap kedua yaitu stabilitas terhadap penyimpanan. Sinergisme surfaktan (Tween 80, Tween 20 dan Span80) dengan perbandingan yang tepat mampu menjaga stabilitas mikroemulsi akibat pemanasan.

\section{Turbiditas Setelah Uji Sentrifugasi}

Hasil analisis keragaman menunjukkan bahwa turbiditas awal dari ke-lima HLB tidak berbeda nyata $(\mathrm{P}>0,05)$, semua HLB menghasilkan mikroemulsi yang transparan, tidak terjadi pemisahan, dan nilai turbiditasnya dibawah $1 \%$. Namun dari semua hasil ini terlihat bahwa mikroemulsi dengan HLB 15 menghasilkan turbiditas paling rendah, yang merupakan hasil yang terbaik dan dapat dilanjutkan uji tahap kedua yaitu stabilitas terhadap penyimpanan.Tetapi penentuan mikroemulsi terbaik tetap dipilih dari rata-rata terendah ketiga hasil diatas. Sentrifugasi menyebabkan mikroemulsi yang terdispersi terpisah dengan fase kontinuenya, bila mikroemulsi tidak stabil. Pengamatan uji sentrifugasi bertujuan untuk mengetahui stabilitas penyimpanan sediaan selama satu tahun oleh pengaruh gaya gravitasi (Mitsui T, 1998).

Hasil penelitian tahap pertama menunjukkan bahwa ke-lima jenis mikroemulsi dapat dikatakan stabil karena, kenampakan yang tetap jernih setelah diberikan perlakuan, tidak adanya endapan pada mikroemulsi yang dihasilkan, serta turbiditasnya yang tetap kurang dari $1 \%$ walaupun setelah diberikan perlakuan. Dari data-data diatas dapat ditentukan bahwa mikroemulsi dengan HLB 13 menunjukkan hasil terbaik. Ini dikarenakan setelah semua uji dilaksanakan, walaupun semua sampel menunjukkan turbiditas kurang dari $1 \%$, namun mikroemulsi dengan HLB 13 menghasilkan rata-rata turbiditas terendah. Mikroemulsi dengan turbiditas terendah inilah yang kemudian akan dilanjutkan dengan penelitian tahap kedua, yaitu diuji stabilitasnya selama masa penyimpanan 7 minggu.

\section{Stabilitas Mikroemulsi Selama Penyimpanan}

Uji stabilitas mikroemulsi dilakukan dengan dua cara yaitu, penyimpanan tanpa perlakuan, dan uji stabilitas dipercepat. Stabilitas penyimpanan mikroemulsi dalam kondisi normal (tanpa perlakuan) dipantau secara rutin setiap minggunya, dengan analisis secara visual dan juga pengukuran turbiditas. Uji stabilitas yang dipercepat dilakukan pada kondisi abnormal yaitu pemberian suhu tinggi $\left(105^{\circ} \mathrm{C}\right.$ selama 5 jam $)$, perlakuan sentrifugasi, dan juga perlakuan pengenceran dengan $\mathrm{pH}$ yang berbeda-beda.

Penelitian tahap kedua ini menghasilkan nilai turbiditas rata-rata mikroemulsi dengan HLB 13 selama penyimpanan 7 minggu, yang dapat dilihat pada Tabel 3.

\section{Turbiditas}

Hasil analisis keragaman menunjukan bahwa turbiditas mikroemulsi kontrol yang disimpan selama 7 minggu tidak berpengaruh nyata $(\mathrm{P}>0,05)$. Ini berarti bahwa, hingga minggu ke-7, mikroemulsi minyak dalam air dengan HLB 13 ini tetap stabil. Kenampakannya tetap jernih, dan tidak ada endapan yang terbentuk.

Nilai turbiditas awal mikroemulsi didapatkan dengan mengukur sampel yang tidak diberi perlakuan apapun. Turbiditasnya dicatat setiap minggunya, untuk menguji stabilitasnya selama disimpan. 
Menurut Dai dkk. (2014), perubahan ukuran droplet minyak mikroemulsi o/w selama penyimpanan disebabkan karena aglomerasi (peristiwa penggabungan koloid dari yang kecil menjadi besar) dari droplet.
Faktor utama yang mempengaruhi aglomerasi adalah zeta potensial dari droplet mikroemulsi. Zeta potensial adalah parameter muatan listrik antara partikel koloid.

Tabel 3. Nilai turbiditas rata-rata mikroemulsi dengan HLB 13 dan hasil pengamatan visual mikroemulsi selama penyimpanan $(\%)$

\begin{tabular}{ccccccccc}
\hline \multirow{2}{*}{$\begin{array}{c}\text { Minggu } \\
\text { ke- }\end{array}$} & awal & $\begin{array}{c}\text { Pemanasan } \\
\left(105^{\circ} \mathrm{C}\right)\end{array}$ & $\begin{array}{c}\text { Sentrifugasi } \\
(4500 \mathrm{rpm})\end{array}$ & $\begin{array}{c}\mathrm{pH}, 5 \\
(1: 1)\end{array}$ & $\begin{array}{c}\mathrm{pH} 3,5 \\
(1: 9)\end{array}$ & $\begin{array}{c}\mathrm{pH} 4,5 \\
(1: 1)\end{array}$ & $\begin{array}{c}\mathrm{pH} 4,5 \\
(1: 9)\end{array}$ & Kenampakan \\
\cline { 2 - 7 } & 0,0494 & 0,0149 & 0,0563 & 0,0103 & 0,0287 & 0,0218 & 0,0138 & Transparan \\
1 & 0,0460 & 0,0103 & 0,0690 & 0,0138 & 0,0299 & 0,0218 & 0,0172 & Transparan \\
2 & 0,0402 & 0,0069 & 0,1001 & 0,0265 & 0,0287 & 0,0184 & 0,0126 & Transparan \\
3 & 0,0241 & 0,0195 & 0,1128 & 0,0149 & 0,0310 & 0,0149 & 0,0218 & Transparan \\
4 & 0,1193 & 0,0414 & 0,1600 & 0,0218 & 0,0345 & 0,0138 & 0,0299 & Transparan \\
5 & 0,2014 & 0,0748 & 0,2141 & 0,0264 & 0,0437 & 0,0126 & 0,0241 & Transparan \\
6 & 0,0552 & 0,0771 & 0,0760 & 0,0322 & 0,0414 & 0,0103 & 0,0230 & Transparan \\
7 & 0,0333 & 0,0805 & 0,0057 & 0,0253 & 0,0402 & 0,0138 & 0,0287 & Transparan \\
\hline
\end{tabular}

\section{Stabilitas Terhadap Pemanasan}

Hasil analisis ragam menunjukkan bahwa setelah dipanaskan $\left(5 \mathrm{jam}, 105^{\circ} \mathrm{C}\right)$ turbiditas mikroemulsi yang disimpan tidak berpengaruh nyata $(\mathrm{P}>0,05)$. Mikroemulsi menunjukkan kenampakan transparan dan indeks turbiditas kurang dari $1 \%$ pada setiap minggunya. Hal ini mengindikasikan bahwa mikroemulsi yang terbentuk mempunyai stabilitas tinggi terhadap pemanasan, dan dapat dikatakan stabil selama penyimpanan.

Uji pemanasan terhadap mikroemulsi merupakan pengujian yang paling kritis. Hal ini disebabkan surfaktan pada suhu tinggi dapat menyebabkan larutan menjadi keruh yang disebut sebagai titik cloud. Suhu tinggi menyebabkan dehidrasi meningkat pada bagian hidrofil, sehingga molekul pengemulsi teragregatasi. Agregat cukup besar mempunyai kemampuan memencarkan cahaya, sehingga menyebabkan larutan kelihatan menjadi keruh. Suhu di atas titik cloud, menyebabkan agregat tumbuh menjadi besar dan mengendap yang dipengaruhi oleh gravitasi. Titik cloud semakin tinggi disebabkan meningkatnya hidrofobik pada molekul surfaktan. Peningkatan hidrofobik disebabkan bagian hidrokarbon meningkat atau ukuran kelompok hidrofil menurun (Aveyard, 1990).

\section{Stabilitas Terhadap Gaya Sentrifugasi}

Hasil analisis keragaman menunjukkan bahwa setelah dilakukan sentrifugasi, hasil turbiditas dari mikroemulsi tidak berpengaruh nyata $(\mathrm{P}>0,05)$. Mikroemulsi tetap jernih, tidak terjadi pemisahan fase atau terbentuk endapan. Hal ini menunjukkan bahwa sediaan mikroemulsi tetap menunjukkan suatu larutan yang terdispersi sempurna setelah penyimpanan selama 7 minggu dan tetap dapat mengalir dengan baik sehingga dapat dikatakan stabil.

Uji sentrifugasi ini dilakukan untuk mengevaluasi kestabilan mikroemulsi. Umumnya diterima bahwa umur mikroemulsi pada kondisi penyimpanan normal dapat diramalkan dengan cepat dengan mengamati pemisahan dari fase terdispersi karena pembentukan krim atau penggumpalan bila mikroemulsi dipaparkan pada sentrifugasi (Leon, 1994).

Sama halnya dengan emulsi, mikroemulsi dikatakan stabil jika tidak menunjukan suatu kerusakan yang serius pada saat disentrifugasi pada kecepatan $4500 \mathrm{rpm}$ 
selama 30 menit. Hasil sentrifugasi dapat diamati dengan adanya pemisahan atau tidak (Cho dkk., 2008).

\section{Stabilitas Terhadap pH}

Hasil analisis keragaman menunjukkan bahwa mikroemulsi menghasilkan turbiditas yang tidak berpengaruh nyata $(\mathrm{P}>0,05)$ setelah dilakukan pengenceran dengan 2 jenis larutan yang memiliki $\mathrm{pH}$ berbeda-beda $(\mathrm{pH}$ 3,5 dan $\mathrm{pH}$ 4,5) dan dengan dua perbandingan yaitu 1:1 dan 1:9. Kenampakan transparan dan tidak terbentuk gel, dengan nilai indeks turbiditas kurang dari $1 \%$ berarti bahwa mikroemulsi yang dihasilkan stabil selama penyimpanan.

Derajat keasaman $(\mathrm{pH})$ yaitu pada $\mathrm{pH} 3,5$ dan $\mathrm{pH}$ 4,5 tidak berpengaruh terhadap mikroemulsi VCO dalam air. Mikroemulsi VCO dalam air dibuat menggunakan surfaktan non ionik, sehingga bagian hidrofilik surfaktan tidak terdisosiasi oleh pengaruh $\mathrm{pH}$. Hal ini kemungkinan yang menyebabkan mikroemulsi VCO dalam air tetap stabil terhadap perubahan $\mathrm{pH}$. McClements dan Decker (2000) melaporkan bahwa emulsi yang distabilkan oleh surfaktan non ionik tidak mengalami perubahan muatan elektrik akibat perubahan $\mathrm{pH}$.

\section{SIMPULAN DAN SARAN}

\section{Simpulan}

Berdasarkan penelitian yang telah dilakukan maka dapat disimpulkan beberapa hal sebagai berikut :

1. HLB 11, 12, 13, 14, 15 yang didapat dengan menggunakan tiga surfaktan, dapat menghasilkan mikroemulsi.

2. HLB yang optimum untuk memperoleh stabilitas mikroemulsi minyak dalam air yang terbaik adalah HLB 13.

3. Mikroemulsi dengan HLB 13 dari 3 surfaktan stabil selama penyimpanan 7 minggu.

\section{Saran}

Berdasarkan penelitian diatas disarankan untuk melakukan penelitian lebih lanjut terhadap aplikasi mikroemulsi dengan HLB 13 dari penggunaan tiga surfaktan ini, sebagai sistem pembawa suatu produk pangan.

\section{DAFTAR PUSTAKA}

Aveyard, B. P. Binks, S. Clark, and P. D. I.

Fletcher. 1990. Cloud Points,

Solubilization and Interfacial Tensions in Systems Containing Nonionic Surfactants. Journal of Chemical Technology and Biotechnology.48:161.

Bakan, J.A. 1995. Microemulsion. Di dalam Encyclopedia of Pharmaceutical Technology. Swarbrick, J., J.C. Boylan (Eds.). Marcel Dekker Inc, New York. p. 335-369.

Chakrabarti, S. 2010. Probing Ingredient Functionalities in Food Systems Using Rheological Methods. Di dalam Ingredient Interactions: Effects on Food Quality, Second Edition. Gaonkar, A., McPherson, A. (Eds.). CRC Press. p. 49-86.

Cho, Y.H., Kim, S., Bae, E.K., Mok, C.K., dan Park, J. 2008. Formulation of a Cosurfactant-Free O/W Microemulsion Using Nonionic Surfactant Mixtures. Journal of Food Science.73: 115 -121.

Dai, J., Kim, S.M., Shin Il-S., Kim, J.D., Lee, H.Y., Shin, W.C. dan Kim, J-C. 2014. Preparation and Stability of Fucoxanthin-Loaded Microemulsions. Journal of Industrial and Engineering Chemistry 20: 2103-2110.

Davies, J.T. 1957. "A Quantitative Kinetic Theory of Emulsion Type, I. Physical Chemistry of the Emulsifying Agent", Gas/Liquid and Liquid/Liquid Interface (Proceedings of the International Congress of Surface 
Activity), pp. 426-38.

Flanagan J, Kortegaard K, Pinder DN, Rades T, Singh H. 2006. Solubilization Of Soybean Oil In Microemulsions Using Various Surfactants. Food Hydrocolloid. 20:253-60.

Fletcher, P.D.I. dan Suhling, K. 1998.Interactions Between Weakly Charged Oil-In-Water Microemulsion Droplets. Langmuir.14: 4065-4069.

Griffin, W.C. 1949. Classification of SurfaceActive Agents By "HLB" Journal of The Society of Cosmetic Chemists.

Hadiwitoyo, S. 2011. Produk Meat Emulsion. Jurusan Teknologi Pangan dan Hasil Pertanian Fakultas Teknologi Pertanian UGM,Yogyakarta

Haerani. 2010. Pemanfaatan Limbah Virgin Coconut Oil (Blondo). Konsentrasi Gizi Program Studi Kesmas PPS Unhas, Makassar.

Leon Lachman, Herbert A. Lieberman dan Joseph L. Kanig. 1994. Teori dan Praktek Farmasi Industri II. Edisi III. Penerjemah Siti Suyatmi. Jakarta: UI Press. 1076-1079.

McClements, D.J. dan Decker, E.A. 2000. Lipid OxidationIn Oil-In-Water Emulsions: Impact Of Molecular Environment On Chemical Reactions In Heterogeneous Food System. Journal of Food Science.65(8): 1270-1282.

McClements, D. J. 2007. Food Emulsions: Principles, Practices, and Techniques, Second Edition. CRC Press. p. 175-231.

McClements, D.J. 2012. Food-grade Microemulsions and Nanoemulsions: Role of Oil Phase Composition on Formation and Stability. Food Hydrocolloids.29: 326-334.

Mitsui, T. 1998.New Cosmetic Science. Elsevier Science B.V:Amsterdam.
Steel, R. G. D. dan J. H. Torrie.1993. Prinsip dan Prosedur Statistika (Pendekatan Biometrik) Penerjemah B. Sumantri. Gramedia Pustaka Utama, Jakarta.

Yaghmur A, Aserin A, Garti N. 2002. Phase Behavior of Microemulsions Based on Food-grade Nonionic Surfactants: Effect Of Polyols And Short-Chain Alcohols. Colloids Surf A: Physicochem Eng Aspects.209:71-81. 